\title{
PENERAPAN REWARD DAN PUNISHMENT DALAM MENINGKATKAN SEMANGAT BELAJAR SISWA DI SDI-TERPADU AL-AZHAR KELURAHAN KOWEL KECAMATAN PAMEKASAN KABUPATEN PAMEKASAN
}

\author{
Abd. Mannan \\ Institut Agama Islam Negeri (IAIN) Madura \\ abdmannan@iainmadura.ac.id
}

Abdur Rahman

SDI-Terpadu al-Azhar Kelurahan Kowel Pamekasan rohman040888@gmail.com

\begin{abstract}
Abstrak
Manusia adalah makhluk individu dan mahluk sosial. Dalam hubungannya dengan manusia sebagai mahluk sosial, terkandung suatu maksud bahwa manusia bagaimanapun juga tidak dapat terlepas dari individu yang lain. Secara kodrati manusia akan selalu hidup bersama. Dalam kehidupan semacam inilah terjadi interaksi. Dengan demikian kegiatan hidup manusia akan selalu dibarengi dengan proses interaksi atau komunikasi, baik interaksi dengan alam lingkungan, interaksi dengan sesamanya, maupun dengan tuhannya, baik itu disengaja maupun tidak disengaja, salah satu bentuk interaksi yang ada adalah interaksi edukatif ialah interaksi yang berlangsung dalam suatu ikatan untuk tujuan pendidikan dan pengajaran. dalam interaksi belajar mengajar salah satu sentralnya ialah siswa, dimana sering dijumpai siswa dengan karakter yang beragam. Ada siswa yang mudah dibina dan ada yang sulit dibina, sebagian giat belajar dan sebagian lain sangat malas belajar, sebagian mereka belajar untuk maju dan sebagian lain belajar hanya untuk terhindar dari hukuman. Berdasarkan hal sebagaimana tersebut di atas penelitian ini bermaksud untuk mengeksplorasi berbagai bentuk reward dan funisment serta efektifitasnya dalam kegiatan pembelajaran khususnya di SDITerpadu al-Azhar Kelurahan Kowel Kecamatan/Kabupaten Pamekasan. Penelitian ini termasuk dalam jenis penelitian deskriptif Adapun pendekatan yang digunakan dalam penelitian ini adalah pendekatan kualitatif. Dari hasil penelitian yang penulis lakukan, diperoleh beberapa temuan bahwa di SDI-Terpadu al-Azhar Kelurahan Kowel Kecamatan/Kabupaten Pamekasan ada beberapa macam bentuk reward dan punishment yang diberikan oleh para guru dalam meningkatkan motivasi belajar siswa, ada efektifitas yang bervariasi dalam pemberian reward dan punishment terhadap motivasi belajar siswa, serta reward dan punishment tersebut diberlakukan setiap saat jika dibutuhkan.
\end{abstract}

Kata Kunci: Reward dan Punishment, Semangat Belajar Siswa

\section{Abstract}

Human is the individual and social creatures. Human can not separate from other human in their relationship as social creature. Human will always live together 
Penerapan Reward dan Punishment dalam meningkatakan semnagat belajar siswa SDITerpadu

\begin{abstract}
based on their character. So that, there is such an interaction in this life. Therefore in human's activities, there will always a process of interaction or communication either the interaction with nature, human, or the interaction with their God intentionally or not. One of the interaction which is exist is the educative interaction. It is the interaction that occurs to aim education and teaching. In the process of teaching learning, one of the central is the students who has various characters. There is a student who is easy to be controlled, some of them are diligent, and some other are very lazy to study. Some of them study to reach progressive and some other just want to avoid a punishment. Based on this case, this research want to explore the effectiveness of kinds of reward and punishment in the process of learning especially in SDI-Terpadu al-Azhar Kelurahan Kowel Kecamatan/Kabupaten Pamekasan. This research include to descriptive research and using Qualitative approach. From the result of research which is writer write, the innovation is there are some kinds of reward and punishment which is given by teacher to increase students' learning motivation. There are some various effectiveness in giving reward and punishment to students' learning motivation and this reward and motivations are done everytime when they need it.
\end{abstract}

\title{
Keywords: Reward and Punishment. Spirit of Students' Learning
}

\section{PENDAHULUAN}

Manusia adalah makhluk individu dan mahluk sosial. Dalam hubungannya dengan manusia sebagai mahluk sosial, terkandung suatu maksud bahwa manusia bagaimanapun juga tidak dapat terlepas dari individu yang lain. Secara kodrati manusia akan selalu hidup bersama. Hidup bersama antar manusia akan berlangsung dalam berbagai bentuk komunikasi dan situasi. Dalam kehidupan semacam inilah terjadi interksi. Dengan demikian kegiatan hidup manusia akan selalu dibarengi dengan proses interaksi atau komunikasi, baik interaksi dengan alam lingkungan, interaksi dengan sesamanya, maupun dengan tuhannya, baik itu di sengaja maupun tidak disengaja. Sebagai makhluk sosial manusia dalam kehidupannya membutuhkan hubungan dengan manusia lain. Hubungan itu terjadi karena manusia menghajatkan manusia lainnya, ketika sesuatu yang akan dilakukan tidak dapat dikerjakan seorang diri. Kebutuhan yang berbeda-beda dan karena saling membutuhkan, membuat manusia cenderung untuk melayani kebutuhan manusia lainnya selain demi kepentingan pribadi. ${ }^{1}$

Pernyataan di atas sangatlah sesuai dengan kenyataan di lapangan, dimana manusia memang tidak bisa hidup sendiri dan selalu membutuhkan terhadap manusia lainnya. Dengan adanya kebutuhan tersebut, maka timbullah interaksi sesama manusia.

\footnotetext{
${ }^{1}$ Syaiful Bahri Djamarah, Guru dan Anak Didik Dalam Interaksi Edukatif (Jakarta: Rineka Cipta, 2010), hlm. 10.
} 
Dari berbagai bentuk interaksi, khususnya mengenai interaksi yang disengaja, ada istilah interakasi edukatif. Interaksi edukatif adalah interaksi yang berlangsung dalam suatu ikatan untuk tujuan pendidikan dan pengajaran. Oleh karena itu, interaksi edukatif perlu dibedakan dari bentuk interaksi yang lain. Dalam arti yang lebih spesifik pada bidang pengajaran, dikenal adanya istilah interaksi belajar mengajar. Dengan kata lain, apa yang dinamakan interaksi edukatif, secara khusus adalah sebagai interaksi belajar mengajar. ${ }^{2}$

Adapun, dalam interaksi belajar mengajar tak luput dari keterlibatan siswa, dimana kita sering menjumpai siswa dengan karakter yang beragam. Ada siswa yang mudah dibina dan ada yang sulit dibina, sebagian giat belajar dan sebagian lain sangat malas belajar, sebagian mereka belajar untuk maju dan sebagian lain belajar hanya untuk terhindar dari hukuman. Sebenarnya sifat-sifat buruk yang timbul dalam diri anak di atas bukanlah lahir dan fitrah mereka. Sifat-sifat tersebut timbul karena kurangnya peringatan sejak dini dari orangtua dan para pendidik. Maka merupakan kesalahan besar apabila kita menyepelekan kesalahan-kesalahan kecil yang dilakukan anak. Sebenarnya, tidak ada pendidik yang menghendaki digunakannya hukuman dalam pendidikan kecuali bila terpaksa. Hadiah atau pujian jauh lebih dipentingkan daripada hukuman. Dalam dunia pendidikan metode ini disebut dengan metode hadiah (reward) dan hukuman (punishment). Dengan metode tersebut diharapkan agar anak didik dapat termotivasi untuk melakukan perbuatan progresif.

Pemberian reward sangat dibutuhkan dalam proses belajar mengajar, dimana seorang guru bisa memancing motivasi dengan pemberian reward tersebut, seperti apa yang dijelaskan oleh Sardiman dalam bukunya interaksi dan motivasinya. Bahwa, Pemberian reward sangat dibutuhkan dalam proses belajar mengajar, karena peserta didik merasa diperhatikan oleh pendidik dan merasa dihargai atas perbuatan yang telah dilakukannya, karena peserta didik sangat memerlukan perhatian dan kasih sayang dari pendidik. Hadiah bisa diberikan sebagai bentuk motivasi, namun tidaklah selalu demikian. Karena hadiah untuk suatu pekerjaan, mungkin tidak akan menarik bagi seseorang yang tidak senang dan tidak berbakat untuk pekerjaan tersebut. ${ }^{3}$

Sama halnya dengan reward, punishment juga dibutuhkan dalam aplikasi pembelajaran, agar peserta didik merasa diawasi oleh pendidik dan merasa akan ada hukuman atas pelanggaran yang akan dilakukan atau yang telah dilakukannya. Memberikan hukuman ialah memberikan atau mengadakan nestapa atau penderitaan dengan sengaja kepada anak yang menjadi asuhan kita dengan maksud supaya penderitaan itu betul-betul dirasakannya, untuk menuju kearah perbaikan. ${ }^{4}$

\footnotetext{
${ }^{2}$ Sardiman, Interaksi \& Motivasi Belajar Mengajar (Jakarta: PT Raja Grafindo Persada, 2012), hlm. 1.

3 ibid, hlm. 92.

${ }^{4}$ Suwarno, Pengantar Umum Pendidikan, (Jakarta: Rineka Cipta, 1992), hlm. 115
} 
Penerapan Reward dan Punishment dalam meningkatakan semnagat belajar siswa SDITerpadu

Sekolah agama terpadu adalah sekolah yang memadukan antara pelajaran umum berdasarkan kurikulum nasional dengan pelajaran agama. Kebanyakan yang dimaksud dengan sekolah agama terpadu adalah sekolah Islam terpadu. Sekolah Dasar Islam terpadu adalah bentuk satuan pendidikan dasar yang menyelenggarakan program pendidikan enam tahun berdasarkan kurikulum nasional yang diperkaya dengan sistem pendekatan islami melalui pengintegrasian antara pendidikan agama dan pendidikan umum, antara sekolah, orang tua dan masyarakat dengan memaksimalkan bagian kognitif, afektif dan psikomotorik dengan harapan peserta didik menjadi manusia yang cerdas, berwawasan luas, kreatif dan bersikap positif. ${ }^{5}$

Adapun lembaga pendidikan SDI-Terpadu al-Azhar Kelurahan Kowel Kecamatan/Kabupaten Pamekasan, berada dilokasi Pondok Pesantren Nurut Tauhid Panggung Kowel Pamekasan. Didirikan oleh Yayasan al-Azhar bekerjasama dengan masyarakat sekitar, hal ini disebabkan oleh banyaknya usulan dari masyarakat terutama dari tokoh-tokohnya yang menginginkan Pesantren tersebut tidak hanya mengelola pendidikan diniyah salafiyah, Mereka juga menginginkan di dalamnya terdapat atau dikelola pendidikan formal yang memuat kurikulum pendidikan Nasional dengan nuansa Pesantren mulai dari jenjang pendidikan yang paling mendasar yaitu Sekolah Dasar (SDITerpadu) hingga jenjang pendidikan selanjutnya, sehingga warga masyarakat sekitar mampu menguasai bukan hanya ilmu agama saja tetapi juga bisa berkompetisi dengan warga Indonesia yang lain dalam hal ilmu umum, untuk menatap suatu harapan Fii adddunyaa hasanah Wa fii al-akhirati hasanah ( bahagia didunia dan akhirat).

Mengacu pada uraian di atas dapat dimengerti bahwa pemberian reward dan punishment itu disamping sebagai metode juga sebagai bentuk motivasi belajar siswa demi terciptanya suatu keberhasilan dalam pendidikan. Sehingga penulis terdorong dan merasa tertarik untuk melakukan penelitian dengan mengangkat sebuah tema "Penerapan Reward dan Punishment dalam Meningkatkan Semangat Belajar Siswa di SDI-Terpadu al-Azhar Kelurahan Kowel Kecamatan/Kabupaten Pamekasan”.

\section{METODE}

Penelitian ini tergolong kedalam penelitian dengan pendekatan kualitatif yang merupakan sebuah penelitian yang berusaha mengungkapkan keadaan yang bersifat alamiah (kenyataan) secara holistic (utuh). Menurut Bodgan Taylor sebagaimana dikutip oleh Lexi J.moleong bahwa pendekatan kualitatif merupakan prosedur penelitian yang menghasilkan data deskriptif berupa kata-kata tertulis atau lisan dari orang-orang dan perilaku yang dapat diamati. ${ }^{6}$

\footnotetext{
${ }^{5}$ Mochamad Yusuf, Obrolan di Bawah Rindangnya Cemara: Kelemahan Sekolah Agama Terpadu, http://www.enerlife.web.id/ diakses pada tanggal 07-06-2013.

${ }^{6}$ Lexi J. Moleong, Metode Penelitian Kualitatif, (Bandung: Remaja Rosda Karya, 2007), hlm. 4.
} 
Jenis penelitian yang digunakan dalam penelitian ini, yaitu menggunakan penelitian deskriptif karena penelitian deskriptif merupakan penelitian yang dimaksudkan untuk mengumpulkan informasi mengenai status suatu gejala yang ada, yaitu keadaan gejala yang sesuai dengan realita yang ada pada saat penelitian dilakukan. Menggambarkan apa adanya tentang suatu keadaan atau variable.

Dengan demikian peneliti akan terbantu untuk menggambarkan secara deskriptif tentang penerapan reward (hadiah) dan punishment (hukuman) dalam pembelajaran sebagai upaya pencapaian standar yang sesuai dengan harapan, sehingga menghasilkan teori bermanfaat bagi kemajuan dan peningkatan semangat belajar bagi siswa di SDITerpadu al-Azhar Kelurahan Kowel Pamekasan.

1. Kehadiran Peneliti

Kehadiran peneliti di lapangan merupakan salah satu langkah penting dan mutlak dalam penelitian kualitatif, karena kehadiran peneliti merupakan upaya untuk memperoleh data atau informasi yang dibutuhkan peneliti sesuai dengan tujuan peneliti. Dalam kajian ini peneliti langsung pada objek sebagai instrument sekaligus pengumpulan data dan juga sebagai pengamat partisipan penuh untuk mendapatkan informasi yang berkenaan dengan penerapan reward (hadiah) dan punishment (hukuman) dalam pembelajaran. Sebelum peneliti ke lapangan atau lokasi penelitian, peneliti sudah mengenal beberapa informan (guru dan siswa) sebagai objek penelitian.

Adapun target kami sebagai peneliti, yang mana peneliti merupakan instrument penting dalam penelitian yang menggunakan pendekatan kualitatif maka, kami rasa sangat perlu atau harus bagi kami untuk hadir ke lokasi penelitian yaitu SDI-Terpadu al-Azhar Kelurahan Kowel Pamekasan.

\section{Lokasi Penelitian}

Peneliti dalam memilih lokasi penelitian ini melalui proses pertimbangan yang dipikirkan secara maksimal karena di lokasi tersebut mengupayakan untuk memberikan pendidikaan secara formal karena yang sebelumnya hanya fokus pada pendidikan diniyah salafiyah saja. Salah satu yang menjadi pertimbangan bagi peneliti dalam pemilihan lokasi penelitian ini adalah di SDI-Terpadu al-Azhar Kelurahan Kowel Pamekasan. Yang mana sekolah ini merupakan lembaga yang berada di tengah-tengah masyarakat dan lembaga ini merupakan lembaga yang menjadikan Islam sebagai dasar pendidikan, sehingga banyak diminati dan lebih dipercaya oleh masyarakat setempat. Di samping itu, lokasinya sangat mudah dijangkau oleh peneliti kerena memang lokasi tersebut sangat dekat dengan rumah peneliti itu sendiri, sehingga peneliti di sini lebih mudah dalam melakukan penelitian ini. 
Penerapan Reward dan Punishment dalam meningkatakan semnagat belajar siswa SDITerpadu

\section{Sumber Data}

Sumber data dalam penelitian ini adalah subjek dimana data diperoleh. ${ }^{7}$ Seperti yang dikatakan oleh Bogdan dan Biklen sebagaimana dikutip oleh Moleong bahwa prosedur penelitian kualitatif ini menghasilkan data diskriptif, yaitu kata-kata orang itu sendiri baik kata-kata itu tertulis maupun berupa ucapan dan prilaku yang dapat diamati. Pendapat ini senada juga dengan yang dikemukakan oleh Lofland bahwa sumber data utama dalam penelitian kualitatif adalah kata-kata dan tindakan, selebihnya adalah data tambahan seperti dokumen dan lain-lain. ${ }^{8}$ Berkaitan dengan hal itu pada bagian ini jenis datanya dibagi ke dalam kata-kata dan tindakan, dan juga sumber data tertulis.

Dalam penelitian ini jenis datanya adalah pertanyaan-pertanyaan yang disampaikan oleh subjek peneliti sesuai dengan seperangkat pertanyaan yang dikemukakan dalam penelitian ini. Dan juga dokumentasi yang bersifat sebagai penguat/bukti dari data yang diperoleh berdasarkan pertanyaan-pertanyaan subjek penelitian tersebut. Adapun sumber data dalam penelitian ini adalah manusia dan non manusia.

a. Sumber data manusia, di antaranya adalah : Kepala Sekolah SDI-Terpadu al-Azhar Kelurahan Kowel Pamekasan itu sendiri, siswa dan segenap dewan guru yang ada, dan kemudian data tersebut dirumuskan dalam bentuk transkip wawancara dan catatan pengamatan lapangan.

b. Sumber data non manusia, diantaranya adalah : Dokumen yang berisi hal-hal penting yang berhubungan dengan penerapan reward dan punishment dalam pembelajaran yang ada di SDI-Terpadu al-Azhar Kelurahan Kowel Pamekasan.

4. Prosedur Pengumpulan Data

Prosedur pengumpulan data yang digunakan dalam penelitian ini melalui Observasi, Wawancara, dan Analisis Dokumentasi. Dan untuk lebih jelasnya maka peneliti akan menjelaskan prosedur tersebut secara rinci.

a. Observasi Menurut Sugiono adalah tekhnik pengumpulan data yang mempunyai ciri yang spesifik apabila di bandingkan dengan tekhnik-tekhnik yang lainnya. ${ }^{9}$ Observasi juga dapat diartikan sebagai pengamatan secara sistematik terhadap gejala yang tampak pada obyek penelitian. ${ }^{10}$

Observasi ada dua macam yaitu:

Observasi Partisipan (Berperan Serta). Dalam Observasi Partisipan disini peneliti terlibat langsung, atau dengan kata lain peneliti itu menjadi salah satu guru yang memang langsung menerapkan reward dan punishment dalam kegiatan pembelajaran di SDI-Terpadu al-Azhar Kelurahan Kowel Pamekasan.

\footnotetext{
${ }^{7}$ Suharsimi Arikunto, Prosedur Penelitian Suatu Pendekatan Praktek, (Jakarta: Rineka Cipta, 2006), hlm. 129.

${ }^{8}$ Moleong, Metodologi Penelitian, hlm. 17.

${ }^{9}$ Sugiyono, Metode Penelitian Kuantitatif Kualitatif dan R \& D, (Bandung: Alfa Beta, 2010), hlm. 145.

${ }^{10}$ S. Margono, Metodologi Penelitian Pendidikan, (Jakarta: Rineka Cipta, 2007), hlm. 158.
} 
Observasi Non Partisipan. Dalam Observasi non partisipan disini peneliti tidak terlibat langsung, dengan kata lain peneliti disini hanya sebagai pengamat responden, dalam artian peneliti itu hanya saja meninjau, memperhatikan, meneliti, dan peneliti tidak pernah menjadi salah satu guru dan tidak pula menerapkan reward dan punishment dalam pembelajaran yang ada di SDITerpadu al-Azhar Kelurahan Kowel Pamekasan.

Adapun jenis observasi yang digunakan oleh peneliti adalah observasi tidak berperan serta atau non partisipan. Artinya peneliti hanya sebagai pengamat penuh sebab peneliti tidak berhak untuk masuk wilayah pribadi objek. Peneliti hanya meninjau dan mengamati bentuk-bentuk reward dan punishment apa saja yang diterapkan dalam pembelajaran.

b. Wawancara

Wawancara adalah percakapan dengan maksud tertentu yang di lakukan oleh dua belah pihak, yaitu pewawancara (interviewer) yang mengajukan pertanyaan-pertnyaan, dan terwawancara (interviewe) yang memberikan respon atau jawaban atas pertanyaan-pertanyaan pewawancara tersebut. ${ }^{11}$ Adapun macam-macam wawancara disini ada dua macam yaitu:

Wawancara Terstruktur

Wawancara terstruktur ini digunakan sebagai tekhnik pengumpulan data, apabila peneliti telah mengetahui dengan pasti tentang apa yang akan diperoleh. $^{12}$ Oleh karena itu maka peneliti tersebut harus menyiapkan instrumen penelitian berupa pertanyaan-pertnyaan sebelum melakukan wawancara, dan pertanyaan-pertanyaan tesebut telah disusun secara tepat oleh peneliti untuk memperoleh jawaban dari hipotesisnya.

Wawancara Tidak Terstruktur

Wawancara tidak terstruktur disini adalah wawancara yang bebas dimana peneliti tersebut tidak menggunakan atau tidak mempunyai pedoman wawancara yang telah disusun secara sistematis dan lengkap untuk pengumpulan datanya. ${ }^{13}$ Jadi di dalam wawancara yang tidak terstruktur disini peneliti memaksudkan untuk memperoleh informasi-informasi yang tidak baku seperti adanya pengecualian, penyimpangan, dan penafsiran yang tidak lazim dalam wawancara yang terstruktur di atas.

Adapun Jenis wawancara yang digunakan dalam penelitian ini adalah wawancara semi terstruktur. Sehingga memudahkan peneliti dalam memperoleh informasi-informasi yang tidak baku seperti adanya pengecualian, penyimpangan, dan penafsiran yang tidak

\footnotetext{
${ }^{11}$ Moleong, Penelitian Kualitatif, hlm. 186.

12 Sugiyono, Penelitian Kuantitatif, hlm. 138.

${ }^{13}$ Ibid, hlm. 140.
} 
Penerapan Reward dan Punishment dalam meningkatakan semnagat belajar siswa SDITerpadu

lazim dalam wawancara terstruktur. Wawancara ini dilakukan kepada kepala sekolah, guru, serta siswa yang ada di lingkungan SDI-Terpadu al-Azhar Kelurahan Kowel Pamekasan.

\section{c. Dokumentasi}

Dokumentasi berasal dari kata dokumen yang berarti barang-barang tertulis. Tekhnik pengumpulan data mengenai hal-hal atau variabel yang diperoleh melalui dokumen-dokumen, hal ini biasanya berupa catatan transkip, buku, kitab-kitab, surat kabar, majalah, agenda dan sebaginya. ${ }^{14}$

Dalam dokumen ini peneliti menghadapi benda mati bukan benda hidup, sehingga hasilnya sangat dipercaya dan tidak akan berubah, apabila dibandingkan dengan metode lain, maka metode ini tidak begitu sulit, apabila ada kekeliruan di kemudian hari sumber datanya masih ada dan tidak berubah berupa absensi, tabel point, perangkat pembelajaran dan lain sebagainya.

\section{Analisis Data}

Menurut Patton, sebagaimana dikutip oleh Buna'i dalam bukunya metodologi penelitian pendidikan, ia mengatakan bahwa yang dimaksud dengan analisis data adalah proses mengatur urutan data, dan mengorganisasikannya kedalam suatu pola, kategori, dan satuan uraian dasar. ${ }^{15}$ Jadi penulis dapat menyimpulkan bahwa Analisis data ini merupakan upaya dalam mencari dan mendata secara sistematis dari hasil catatan observasi, wawancara dan lain sebagainya, dan hal itu untuk meningkatkan pemahaman peneliti mengenai kasus yang diteliti dan menyajikannya sebagai temuan bagi orang lain. Adapun langkah-langkah yang ditempuh dalam analisis data selama pengumpulan data, yaitu :

a. Cheking

Cheking ini adalah mengecek atau memeriksa kembali data yang berasal dari transkip wawancara, observasi, dan dari dokumentasi dengan maksud untuk mengetahui tingkat kelengkapan data atau informasi yang diperlukan.

b. Coding (pemberian kode)

Pemberian kode dimaksudkan untuk menentukan data atau informasi berdasarkan teknik pengumpulan data (wawancara dan observasi). Adapun kode yang digunakan oleh peneliti dalam penelitian ini adalah sebagai berikut :

Kode wawancara

(W-1/ KS/LK/Tgl-Bln-Thn/SN)

(W-2/GR/LK/Tgl-Bln-Thn/SN)

(W-3/SW/LK/Tgl-Bln-Thn/SN)

Keterangan :

W-1/KS : Wawancara dengan kepala sekolah

\footnotetext{
${ }^{14}$ Buna'i, Metodologi Penelitian Pendidikan, (Pamekasan: STAINPamekasan Press, 2006), hlm. 107.

15 Ibid, 48.
} 


$\begin{array}{ll}\text { W-2/GR } & \text { : Wawancara dengan guru } \\ \text { W-3/SW } & \text { : Wawancara dengan siswa } \\ \text { LK } & \text { : Lokasi Wawancara } \\ \text { SN } & \text { : Nomor Soal }\end{array}$

Kode observasi

(0-1/LK/Tgl-Bln-Thn)

Keterangan :

0-1/GR : observasi pada guru

LK : Lokasi Observasi

Tgl : tanggal observasi

Bln : bulan observasi

Thn : tahun observasi

Kode dokumentasi

(D/LK/Tgl-Bln-Th)

Keterangan :

D : Dokumentasi

LK : Lokasi

Tgl : Tanggal

Bln : Bulan

Thn : Tahun

c. Organizing

Setelah mengadakan pengecekan data, maka selanjutnya mengadakan pengorganisasian data, Pengorganisasian data ini dilakukan dengan memilah atau mengklasifikasikan data sesuai dengan arah fokus penelitian. Pengklasifikasian data ini peneliti pisah dalam lembar data tersendiri untuk memudahkan penelitian dalam menyusun data dalam rangka menganalisis data.

Dalam penelitian kualitatif ini, analisis data dilakukan secara bersamaan dengan pengumpulan data ataupun sesudahnya, dimana pekerjaan pengumpulan data dalam penelitian kualitatif ini harus diikuti dengan penulisan, mengedit, mengklasifikasi, mereduksi, dan menyajikan data.

Analisis data tersebut ditandai dengan proses analisis induktif/dari khusus ke umum sehingga diperoleh temuan penelitian.

6. Pengecekan Keabsahan Data

Peneliti melakukan pengecekan keabsahan data, dilakukan dengan cermat dan hatihati agar penelitian ini tidak sia-sia dan bukan hanya sekedar menjadi serimunial belaka 
Penerapan Reward dan Punishment dalam meningkatakan semnagat belajar siswa SDITerpadu

sehingga kegunaan dan manfaat penelitian ini benar-benar dirasakan oleh peneliti itu sendiri dan orang lain.

Untuk mengecek keabsahan atau validitas data yang diperoleh di lapangan maka peneliti disini perlu untuk mengemukakan teknik yang diperlukan peneliti dalam mengukur keabsahan temuan tersebut, yaitu sebagai berikut:

a. Perpanjagan Kehadiran Peneliti

Kehadiran peneliti dalam pengumpulan data sangat vital. Dengan memperpanjang dan menambah kehadiran penelitian, maka peneliti dapat menguji kebenaran informasi dan membangun kepercayaan subyek.

b. Observasi Yang Diperdalam

Observasi yang diperdalam merupakan peningkatan intensitas ketekunan dalam melakukan pengamatan (pengamatan dengan lebih jeli dan lebih seksama) untuk memperoleh data yang akurat sesuai dengan masalah yang diteliti.

c. Triangulasi

Triangulasi adalah tekhnik pemeriksaan keabsahan data yang memanfaatkan sesuatu yang lain di luar data itu untuk keperluan pengecekan atau sebagai pembanding tehadap data itu. ${ }^{16}$ Jadi penulis dapat memberikan kesimpulan bahwa triangulasi itu merupakan cara yang baik untuk menghilangkan perbedaan-perbedaan konstruksi kenyataan yang ada dalam konteks suatu studi di waktu mengumpulkan data tentang berbagai kejadian dan hubungan dari berbagai pandangan. Dengan kata lain bahwa dengan triangulasi, peneliti dapat me-rechek temuannya dengan jalan membandingkannya dengan berbagai sumber, metode atau teori. Untuk itu maka peneliti dapat melakukan dengan jalan:

Mengajukan berbagai macam variasi pertanyaan

Mengeceknya dengan berbagai sumber data

Memanfaatkan berbagai metode agar pengecekan kepercayaan data dapat dilakukan. ${ }^{17}$

d. Uraian Rinci

Yang di maksud uraian rinci adalah data yang diperoleh itu dipaparkan secara rinci sehingga peneliti/penulis serta pembaca dapat mengerti dan mengetahui temuan yang di hasilkan dari penelitian ini. Uraian rinci ini terutama ditekankan pada fokus penelitian yang di maksudkan oleh peneliti dalam studi ini.

e. Analisis Kasus Negatif

\footnotetext{
${ }^{16} \mathrm{Ibid}, \mathrm{hlm} .116$.

${ }^{17}$ Moleong, Metodologi Penelitian, hlm. 330-332.
} 
Tekhnik ini bertujuan untuk mengecek keabsahan temuan dengan menganalisis isu-isu atau data yang tidak sesuai dengan pola dan kecenderungan informasi sehingga data tersebut menunjukkan kebenaran sebagaimana adanya.

\section{HASIL PENELITIAN DAN PEMBAHASAN}

\section{Bentuk-bentuk reward dan punishment}

Penggunaan metode reward dan punishment dalam proses pendidikan di SDITerpadu al-Azhar Kowel Pamekasan tampak di dalam kelas pada saat kegiatan pembelajaran berlangsung mislanya, ketika siswa bisa menjawab soal dengan cepat dan tepat guru langsung memberikan pujian atau tepuk tangan. Juga di luar kelas pada saat jam istirahat atau pada pelaksanaan shalat jamaah bersama, misalnya, ketika ada siswa membuang sampah tidak pada tempatnya maka guru yang kebetulan melihat akan langsung memberikan hukuman atau punishment pada siswa yang bersangkutan.

Dalam pelaksanaanya pemberian reward dan punishment di SDI-Terpadu al-Azhar, sejalan dengan pernyataan Sukadi dalam bukunya yang berjudul Guru Powerful Guru Masa Depan bahwa, reward akan efektif apabila diberikan segera setelah perilaku baik dikerjakan dan jangan ditunda-tunda. ${ }^{18}$ Begitu pula dengan punishment, Lakukan dengan segera setelah perilaku salah itu dilakukan oleh siswa, karena hukuman yang ditunda-tunda bisa menyebabkan anak melupakan kesalahannya atau kita lupa dengan peristiwa itu. ${ }^{19}$

Adapun bentuk-bentuk reward dan punishment yang diberikan :

a. Bentuk-bentuk reward

Adapun bentuk-bentuk reward yang diberikan kepada siswa yang berprestasi dalam meningkatkan semangat belajar siswa di SDI-Terpadu Al-Azhar Kelurahan Kowel Kecamatan/Kabupaten Pamekasan sangatlah bergagam, seperti pemberian hadiah, pujian bagi siswa, tepuk tangan dan memberikan point nilai bagi yang berprestasi tinggi. Dengan demikian siswa atau anak didik akan senang dalam mengikuti pembelajaran dan akan meningkatkan motivasi belajar mereka.

Hal tersebut sesuai dengan apa yang ditulis oleh Ramayulis dan Samsul Nizar menyebutkan dalam bukunya yang berjudul Filsafat Pendidikan Islam ganjaran atau hadiah dapat diberikan oleh pendidik dalam bentuk yang beragam. Misalnya, pendidik menganguk-angguk kepala tanda senang dan membenarkan suatu jawaban yang diberikan oleh seorang peserta didik. Pendidik memberikan kata-kata yang menyanjung (pujian). Pendidik memberikan benda-benda yang menyenangkan dan berguna bagi peserta didik, dan sebagainya. ${ }^{20}$

\footnotetext{
${ }^{18}$ Sukadi, Guru Powerful, Guru Masa Depan, (Bandung: Kolbu, 2006), hlm. 108.

${ }^{19}$ Ibid, hlm. 129.

${ }^{20}$ Ramayulis \& Samsul Nizar, Filsafat Pendidikan Islam, (Jakarta: Kalam Mulia, 2011), hlm. 254-255.
} 
Penerapan Reward dan Punishment dalam meningkatakan semnagat belajar siswa SDITerpadu

Selain Ramayulis dan Samsul Nizar, Ngalim Purwanto juga menyatakan bahwa dalam memberikan reward kepada siswa untuk meningkatkan motivasi belajar mereka bisa menggunakan berbagai macam betuk reward. Antara lain, guru mengangguk-angguk tanda senang dan membenarkan suatu jawaban yang diberikan oleh seorang anak. Guru memberikan kata-kata yang menggembirakan (pujian) seperti, "rupanya sudah baik pula tulisanmu, min. kalau kamu terus berlatih, tentu akan lebih baik lagi”. Pekerjaan dapat juga menjadi suatu ganjaran. Contoh, "engkau akan segera saya beri soal yang lebih sukar sedikit, karena yang nomor 3 ini rupa-rupanya agak terlalu baik engkau kerjaan." Ganjaran yang di tujukan kepada seluruh kelas sering sangat perlu. Misalnya, "karena saya lihat kalian telah bekerja dengan sangat baik dan cepat selesai, sekarang (bapak guru) akan mengisahkan sebuah cerita yang bagus sekali." Ganjaran untuk seluruh kelas dapat juga berupa bernyanyi atau berdarma-wisata. Ganjaran dapat juga berupa benda-benda yang menyenangkan dan berguna bagi anak-anak. Misalnya pensil, buku tulis, gula-gula atau makanan lain. $^{21}$

Dari beberapa bentuk atau macam-macam reward di atas bertujuan supaya siswa atau peserta didik lebih senang dan termotivasi dalam meningkatkan belajarnya dan bentuk-bentuk reward diatas digunakan dalam kegiatan pembelajaran di SDI-Terpadu alAzhar Kelurahan Kowel Kecamatan/Kabupaten Pamekasan, seperti pemberian hadiah, memberikan pujian bagi siswa, tepuk tangan yang dijadikan sebagai penghargaan, bercerita atau bermain ketika masih ada waktu jam pembelajaran tersisa, dan memberikan point nilai bagi yang berprestasi tinggi. Dengan demikian siswa atau anak didik akan senang dalam melakukan pembelajaran dan akan meningkatkan motivasi belajar mereka.

b. Bentuk-bentuk punishment

Sama halnya dengan reward, punishment yang dipakai oleh guru dalam kegiatan pembelajaran di SDI-Terpadu al-Azhar Kelurahan Kowel Kecamatan/Kabupaten Pamekasan juga beragam, seperti mengingatkan atau memberi peringatan-peringatan, memberikan tugas tambahan, menerangkan pelajaran, disuruh berdiri atau maju ke depan, membayar uang kas bagi yang tidak taat aturan atau melanggar ketertiban dan memberikan pengarahan-pengarahan.

Menurut Sukadi dalam bukunya yang, secara garis besar, ada tiga macam bentuk hukuman yang dapat diberikan pendidik kepada peserta didik, yaitu:

1. Membuat siswa melakukan perbuatan yang tidak menyenangkan (restitusi).

2. Mencabut kegemaran atau kesempatan anak yang dimiliki siswa (deprivasi).

3. Menimpakan rasa sakit berbentuk kejiwaan atau fisik terhadap siswa. ${ }^{22}$

\footnotetext{
${ }^{21}$ Ngalim Purwanto, Ilmu Pendidikan Teoritis Dan Praktis, (Bandung: Remaja Rosdakarya, 1998), hlm. 183.

${ }^{22}$ Sukadi, Guru Powerful, hlm. 125.
} 
Demikian pendapat Sukadi dimana hukuman yang diberikan oleh pendidik kepada peserta didik besar kemungkinan akan berpengaruh terhadap peserta didik dalam merubah perilaku dari melanggar menjadi tidak melanggar. Adapun yang digunakan di lembaga SDI-Terpadu al-Azhar Kelurahan Kowel Kecamatan/Kabupaten Pamekasan memakai bentuk-bentuk punishment seperti mengingatkan atau memberi peringatan-peringatan, dan memberikan pengarahan-pengarahan, memberikan tugas tambahan, menerangkan pelajaran, disuruh berdiri atau maju ke depan, membayar uang kas bagi yang tidak taat aturan atau melanggar ketertiban, merupakan hukuman yang bersifat restitusi.

Ngalim Purwanto juga menjelaskan dalam bukunya, bahwa bentuk hukuman itu dibagi menjadi dua macam. Yaitu:

Hukuman preventif, yaitu hukuman yng dilakukan dengan maksud agar tidak atau jangan terjadi pelanggaran. Hukuman ini bermaksud untuk mencegah jangan sapai terjadi pelanggaran sehingga hal itu dilakukannya sebelum pelanggaaran itu dilakukan.

Hukuman represif, yaitu hukuman yang dilakukan oleh karena adanya pelanggaran, oleh adanya dosa yang telah diperbuat. Jadi, hukuman ini dilakukan setelah terjadi pelanggaran atau kesalahan. ${ }^{23}$

Dari pernyataan diatas tentang bentuk hukuman juga dipakai dalam kegiatan pembelajaran di SDI-Terpadu al-Azhar Kelurahan Kowel seperti mengingatkan atau memberi peringatan-peringatan, dan memberikan pengarahan-pengarahan, punishment ini termasuk dalam kategori hukuman preventif, sedangkan memberikan tugas tambahan, menerangkan pelajaran, disuruh berdiri atau maju ke depan, membayar uang kas bagi yang tidak taat aturan atau melanggar ketertiban termasuk kategori hukuman represif, berbagai bentuk hukuman tersebut sangat berpengaruh bagi siswa dimana siswa akan mengetahui tindakan yang mereka lakukan merupakan perbuatan tercela dan diharapkan akan muncul kesadaran dalam diri mereka untuk tidak mengulangi perbuatan tersebut.

\section{Efektivitas antara Reward dan Punishment}

Dalam setiap kegiatan pembelajaran baik reward maupun punishment, keduanya sama-sama memberikan dampak terhadap semangat belajar siswa dan juga berdampak terhadap perilaku siswa dari negatif menuju positif. Misalnya, pemberian reward bisa menumbuhkan motivasi siswa dalam pembelajaran dan juga berprilaku yang positif, bahkan menimbulkan persaingan secara sehat untuk menuju prestasi yang lebih baik lagi. Sedangkan punishment, akan memunculakan kesadaran diri siswa untuk tidak mengulangi kesalahan atau tindakan negatif yang telah dilakukan, dan juga akan berusaha untuk mengindari perbuatan tercela yang lain.

Adapun efek tersebut timbul karena siswa melakukan tindakan yang baik sehingga guru memberikan reward dan ketika siswa melakukan hal yang negatif maka guru

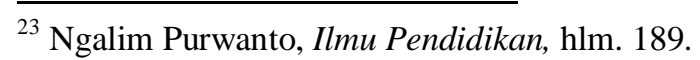


Penerapan Reward dan Punishment dalam meningkatakan semnagat belajar siswa SDITerpadu

memberikan punishment, hal ini sesuai dengan pernyataan Ramayulis bahwa, metode targhib (hadiah atau ganjaran) dan tarhib (hukuman), adalah cara mengajar dimana guru memberikan materi pembelajaran dengan menggunakan ganjaran terhadap kebaikan atau hukuman terhadap keburukan, agar peserta didik melakukan kebaikan dan menjauhi keburukan. ${ }^{24}$

Adapun efektivitasnya terhadap motivasi belajar siswa baik reward maupun punishment sama-sama efektif dan sangat tepat digunakan dalam pendidikan karena bisa membuat siswa senang dan termotivasi di dalam meningkatkan belajarnya dan siswa juga patuh terhadap guru dan tak akan mengulangi kesalahan yang sudah diperbuat dan berusaha untuk lebih baik dalam belajarnya maupun dalam perilakunya.

Memberikan reward (hadiah) atas perilaku atau sikap siswa yang baik ini merupakan cara pengendalian perilaku siswa secara positif. Hal ini pun sangat efektif untuk menumbuhkan rasa percaya diri mereka. Mereka akan merasa dihargai dan dihormati, serta merasa diperhatikan dan diakui eksistensinya. ${ }^{25}$

Sebagaimana pernyataan sebelumnya, pemberian reward sangat efektif dimana dengan adanya pemberian reward tersebut anak didik bisa meningkatkan motivasinya untuk lebih giat lagi dalam hal positif. Menurut Syaiful Bahri Djamarah, pemberian hadiah yang sederhana perlu digalakkan karena relatif murah dan dirasakan cukup efektif untuk memotivasi anak didik dalam kompetensi belajar. Jangan menunggu hadiah yang mulukmuluk dan mahal dengan maksud membanggakan diri sendiri. ${ }^{26}$

Dalam hal punishment atau hukuman, menurut al-Ghazali sebagaimana dikutip oleh Zainuddin dalam bukunya bahwa, boleh memberikan hukuman kepada siswa selama dalam batas-batas tertentu sehingga tidak terlalu menyakitkan badan dan jiwa anak, apalagi sampai menjadikan cacat tubuh. Dan ini diberikan kalau anak itu betul-betul bandel dan kurang ajar yang berlebih-lebihan. Selain itu hukuman yang diberikan berupa seuatu yang mendidik dan memberikan efek jera. ${ }^{27}$

\section{KESIMPULAN}

Berdasarkan analisis data dapat disimpulkan bahwa, Penggunaan metode reward dan punishment dalam proses pendidikan di SDI-Terpadu al-Azhar Kowel Pamekasan tampak di dalam kelas pada saat kegiatan pembelajaran berlangsung misalnya, ketika siswa bisa menjawab soal dengan cepat dan tepat guru langsung memberikan pujian atau tepuk tangan. Juga di luar kelas pada saat jam istirahat atau pada pelaksanaan shalat jamaah bersama, misalnya, ketika ada siswa membuang sampah tidak pada tempatnya maka guru

\footnotetext{
${ }^{24}$ Ramayulis, Ilmu Pendidikan Islam, (Jakarta: Kalam Mulia, 2010), hlm. 197.

${ }^{25}$ Sukadi, Guru Powerful, hlm. 106

${ }^{26}$ Syaiful Bahri Djamarah, Psikologi Belajar, (Jakarata: Rineka Cipta, 2011), hlm 161

${ }^{27}$ Zainuddin, Seluk-Beluk Pendidikan Dari al-Ghazali, (Jakarta: Bumi Aksara, 1991.), hlm. 88
} 
yang kebetulan melihat akan langsung memberikan hukuman atau punishment pada siswa yang bersangkutan.

Baik reward maupun punishment yang diberikan oleh guru di SDI-Terpadu alAzhar Kowel Pamekasan sangatlah beragam. Bentuk reward yang digunakan antara lain seperti pemberian hadiah, pujian bagi siswa, tepuk tangan dan memberikan point nilai bagi yang berprestasi tinggi. Sedangkan bentuk punishment yang digunakan antara lain mengingatkan atau memberi peringatan-peringatan, memberikan tugas tambahan, menerangkan pelajaran, disuruh berdiri atau maju ke depan, membayar uang kas bagi yang tidak taat aturan atau melanggar ketertiban dan memberikan pengarahan-pengarahan.

Adapun efektivitas antara reward dan punishment terhadap motivasi belajar siswa sama-sama efektif dan sangat tepat digunakan dalam pendidikan karena bisa membuat siswa senang dan termotivasi di dalam meningkatkan belajarnya dan siswa juga patuh terhadap guru dan tak akan mengulangi kesalahan yang sudah diperbuat dan berusaha untuk lebih baik dalam belajarnya maupun dalam perilakunya.

\section{DAFTAR PUSTAKA}

Arikunto, Suharsimi. Prosedur Penelitian Suatu Pendekatan Praktek, Jakarta: Rineka Cipta, 2006.

Buna'i. Metodologi Penelitian Pendidikan, Pamekasan: STAIN Pamekasan Press, 2006.

Djamarah, Syaiful Bahri. Guru dan Anak Didik Dalam Interaksi Edukatif, Jakarta: Rineka Cipta, 2010.

Margono, S. Metodologi Penelitian Pendidikan, Jakarta: Rineka Cipta, 2007.

Moleong, Lexi J. Metode Penelitian Kualitatif, Bandung: Remaja Rosda Karya, 2007.

Purwanto, Ngalim. Ilmu Pendidikan Teoritis Dan Praktis, Bandung: Remaja Rosdakarya, 1998.

Ramayulis \& Samsul Nizar. Filsafat Pendidikan Islam, Jakarta: Kalam Mulia, 2011.

Ramayulis. Ilmu Pendidikan Islam, Jakarta: Kalam Mulia, 2010.

Sardiman. Interaksi \& Motivasi Belajar Mengajar, Jakarta: PT Raja Grafindo Persada, 2012.

Sugiyono. Metode Penelitian Kuantitatif Kualitatif dan $R \& D$, Bandung: Alfa Beta, 2010.

Sukadi. Guru Powerful, Guru Masa Depan, Bandung: Kolbu, 2006.

Suwarno. Pengantar Umum Pendidikan, Jakarta: Rineka Cipta, 1992.

Yusuf, Mochamad. Obrolan di Bawah Rindangnya Cemara: Kelemahan Sekolah Agama Terpadu, http://www.enerlife.web.id/.

Zainuddin. Seluk-Beluk Pendidikan al-Ghazali, Jakarta: Bumi Aksara, 1991. 